\title{
Redi's denial of spontaneous generation in insects
}

Part of the legacy of the ancient to the early modern world was the belief that living creatures were generated in two distinct ways. The first, generatio univoca, was from parents of the same species. But another type of generation was believed to be common, especially for lower, or at least smaller, animals 'spontaneous generation', generatio æquivoca, in which living things originated from non-living materials such as mud, slime or rotting vegetable or animal matter. Once generated, these creatures might breed by sexual reproduction, but were claimed by some authorities, following Aristotle, not to breed true but to give rise to a different species. For Aristotle, 'the issue of copulation in lice is nits; in flies, grubs; in fleas, grubs egg-like in shape'.' A particularly common source of 'spontaneously' generated life were the grubs or maggots that appear in rotting animal matter and give rise to flies. The appearance of maggots apparently spontaneously, and of flies from these maggots, seemed to confirm both the occurrence of generatio æquivoca and that its progeny did not breed true. The existence of spontaneous generation was accepted, apparently without question, until the second half of the seventeenth century, and the belief persisted in one form or another until well into the nineteenth.

Francesco Redi (1626-98) was the first to show that maggots arise in rotting meat only if flies have access to it, and he did this by a series of carefully controlled observations that are a model of the new experimental method then just being developed. Redi, a poet as well as physician to the Medici grand dukes Fernando II and Cosimo III of Florence, was one of a group of Italian experimental philosophers, the best known of whom is his contemporary Galileo. Redi's book on the generation of insects was first published in Italian in 1668, followed by Latin translations in $167 \mathrm{I}$ and later. The College has copies of the first (Italian) edition and a Latin version of $1686 .{ }^{2}$

The title page of the first edition (shown above) is interesting. It is printed with alternate lines of letterpress in red and in black - the red text is pale grey in the illustration - and says that the contents were contained in a letter to Redi's friend Carlo Dati. Probably this is to be taken as a dedication rather than a claim that the whole text was sent as a letter. The woodcut on the title page (Figure I) is a motif of the curiously named Academia della Crusca ('Academy of the bran'), of which Redi and Dati were both members. The image is of a mechanical sieve for separating bran from flour - the
English analogy would be wheat from chaff - representing the Academy's aim of preserving the best of the Tuscan language and rejecting the rest. Dati is an interesting figure who is credited with the invention of 'eyeglasses'.

Rather than summarising Redi's experiments to test whether maggots arise 'spontaneously' in rotting flesh, I shall let him speak for himself through my English translations from the 1686 Latin edition. First, a general statement that shows that, although Redi denied the 'spontaneous' generation of animals, he did believe they might sometimes arise from plants:

$\ldots$ and that all [creatures] whether in previous ages or at present, which appear to arise either in the soil or from the soil, really and in fact are generated from seeds of plants unless they are born from their own animals [i.e. animals of the same species] so that by the action of their own seed their species are conserved. ${ }^{2}$ (p. I7)

An anonymous reviewer in 1670 commented:

This author esteems it not absurd to affirme, that the Anima or Power which is able to produce Flowers and Fruits in living Plants, may be alike capable to breed Worms in them since that Soul is so powerful, as to cause Plants to feed, to grow and to produce seed, as it doth in Animals... Having establisht this ground against Aequivocal generation, he proceeds to particulars [...]

- Phil Trans, Vol. 5, I670, p. II 76

Redi's belief in the generation of animals from plants probably derives from his observations of 'worms' in

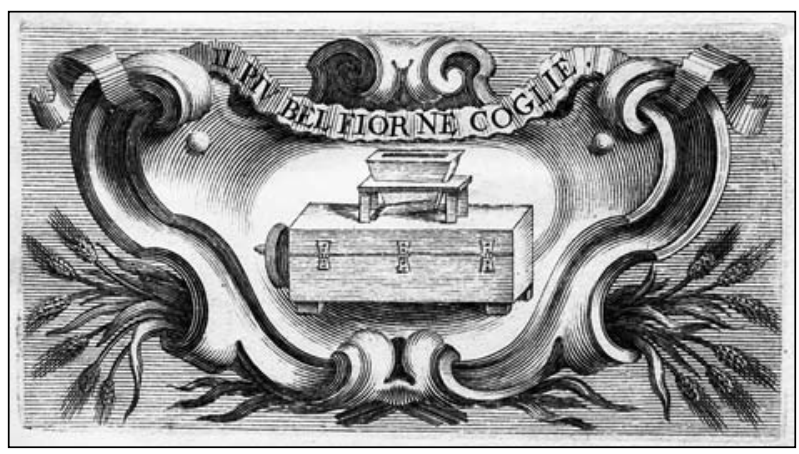

FIGURE I Device of the Academia della Crusca, showing a sieve to separate the grain from the chaff. The motto, from Petrarch, means 'she picks the fairest flower'. 
plant galls; he did not know that these arise from ova deposited by insects. However, in the experiments on rotting tissue Redi was able to control his experimental conditions admirably.

The descriptions of the experiments are spread over many pages; here are some examples.

Hence, in the middle of the month of July, I put into four flasks with wide necks, one snake, some river fish, four eels from the river Arno and a piece of a suckling calf, then closed them up and sealed their mouths very well with paper and string. Then, I put the same amount of [the] materials into [flasks] whose mouths were not closed. Not much time passed until maggots appeared in the fish and meat left in those [open] vessels with flies going out and in as they pleased. But, truly, in the sealed flasks I saw not a single maggot arise, not even after a month had passed since the bodies had been put into them. However, if there was some filth on the paper, or there was a maggot which managed by its exertions to find its way into the flask through a crack that it found [in the paper], and managed to stay alive, in all those flasks that were entered thus [the contents] then became rotten and corrupt. ${ }^{2}$ (p. 32-33)

Not content with a single experiment, Redi repeated it many times:

Nor, however, was I content with this single experiment, but at various times and using various vessels, I carried out a great many other experiments in the same way. ${ }^{2}$ (p. 34)

$\ldots$ and in not a single closed vessel was anything ever generated: but, truly, in the others maggots were born which changed into eggs and, finally, into ordinary flies, in the same way. And thus in a closed vessel I never saw anything to be born, but truly in an open vessel maggots were born, from which, when they had been transformed into eggs, flies came forth of the very same species from which the maggots had been generated. ${ }^{2}$ (p. 35)

Using the same word, 'eggs' (Latin, ova), to denote the intermediate stage between maggot and fly as well as that between fly and maggot, gives one momentary pause, but the conclusion, that rotting tissue separated from the outside world does not generate maggots, is entirely clear.

Then Redi elaborated the experiment to forestall criticism:

To allow us return to the argument I need to tell you as much as I think is required - as though to propitiate

\section{REFERENCES}

I Aristotle. Historia animalium. Trans. DAW Thompson. Oxford: Clarendon Press; 1910. Book 5, chapter I. the shades - about tissues of dead animals, that they generate no maggots unless seed from other living creatures reaches them; however, lest everyone doubt me, and lest it be a cause of opposition, that someone raises a question about the closed vessels, because the surrounding air cannot enter or leave nor renew itself freely, I was led to attempt another experiment. I put flesh and fish into a very large vessel, and, so that the air could penetrate into it, this vessel, closed by a [layer of] the thinnest Neapolitan gauze was put into a box suitable for keeping out flies, and [this also was] closed with a layer of the same Neapolitan gauze.

And not a single maggot appeared on the meat or on the fish; however, it was not uncommon to see several wandering around on the upper layer [of gauze] and on the surface of the box, attracted there by the smell of meat. If they penetrated through tiny holes in the layer of gauze into the box and if they were not rapidly removed they might penetrate into the vessel itself; they were so active and persistent that they might succeed in arriving there. I once saw two maggots after they had easily penetrated the first layer and were then stuck on the second [layer of gauze] that closed the opening of the vessel; they wriggled so vigorously that they would then have penetrated the second piece of gauze, and nothing then remained [to prevent] them from eating their fill of the meat. And it was most fortunate that, in the meantime, I saw large flies flying around and eating and buzzing by turns, settling down on the first [layer of] gauze, and at that moment depositing maggots: and I noticed that those flies deposited six or seven maggots in each place; and another [fly] put them [maggots] out in the air before it touched the gauze. And perhaps these chanced to be the same species [of fly] of which Scaliger speaks, saying that a large fly that he caught by chance left behind in his hand some small worms, from which he argues that flies in general produce not eggs but living worms; but how much this learned and distinguished man is in error will be quite apparent from what has been said above. ${ }^{2}$ (p. 39-4I)

By his comment on Scaliger, Redi shows that he was quite aware that most flies lay eggs, which then hatch into maggots. However, from the earlier part of this passage in isolation, one might be forgiven for supposing that Redi, like Scaliger, had concluded that flies generally lay maggots. There are, of course, viviparous flies, although one cannot help feeling that Redi was unlucky if he encountered them in his experiment.

IML Donaldson, Honorary Librarian, RCPE (email: i.m.l.d@ed.ac.uk)
2 Redi F. Francisci Redi, Patricii Aretini, Opusculorum pars prior, sive experimenta circa generationem insectorum. Amsterdam: Apud Henricum Wetstenium; 1686. 